\title{
Chapter 12 \\ Concept for the Monitoring \\ of Climate Induced Impacts on Rock \\ Ptarmigan (Lagopus muta) in Triglav \\ National Park, Slovenia
}

\author{
Tina Petras
}

\subsection{Introduction to the Case Study}

Part of the main management goals for the alpine ecosystem in Triglav National Park (TNP) are the (1) preservation of a representative portion of high mountain grasslands and pastures, (2) prevention the disturbances in the living environment of the species, (3) establish a network of habitats connection which will enable the preservation of grassland ecosystems and (4) maintaining viable population of mountain species. To monitor effects of climate change key indicators that correspond to these aims and relate to climate change have been chosen.

In the following paper, the case study on the population monitoring of rock ptarmigan (Lagopus muta) in TNP is presented. Rock ptarmigan is considered an indicator species for the extreme alpine environment with good response to human impacts.

To understand the population dynamics of a species with regard to environmental and/or human impacts, long-term surveys are essential. With monitoring indicators it is possible to evaluate management strategies. For the appropriate conservation of viable species populations, aspects of the environment, distribution, biotic interactions, morphology, physiology, demography, behaviour, genetics and human impacts should be addressed in the monitoring programme (Primack 2006). However, monitoring alone produces no information on the causes and consequences of particular conditions in ecosystems and for population's dynamics. Therefore, it should be complemented by scientific research (Alexander 2008) on key environmental factors and the population biology of key species.

The rock ptarmigan is an arctic-alpine grouse species (Fig. 12.1) widespread throughout the northern Eurasia and North America (Storch 2007). It inhabits opened habitats, in Alps above the tree-line, mainly between 1,700 and 2,400 $\mathrm{m}$ a.s.l.

\footnotetext{
T. Petras $(\bowtie)$

Triglavski narodni park, Ljubljanska cesta 27, 4260 Bled, Slovenia

e-mail: tina.petras@gmail.com
} 


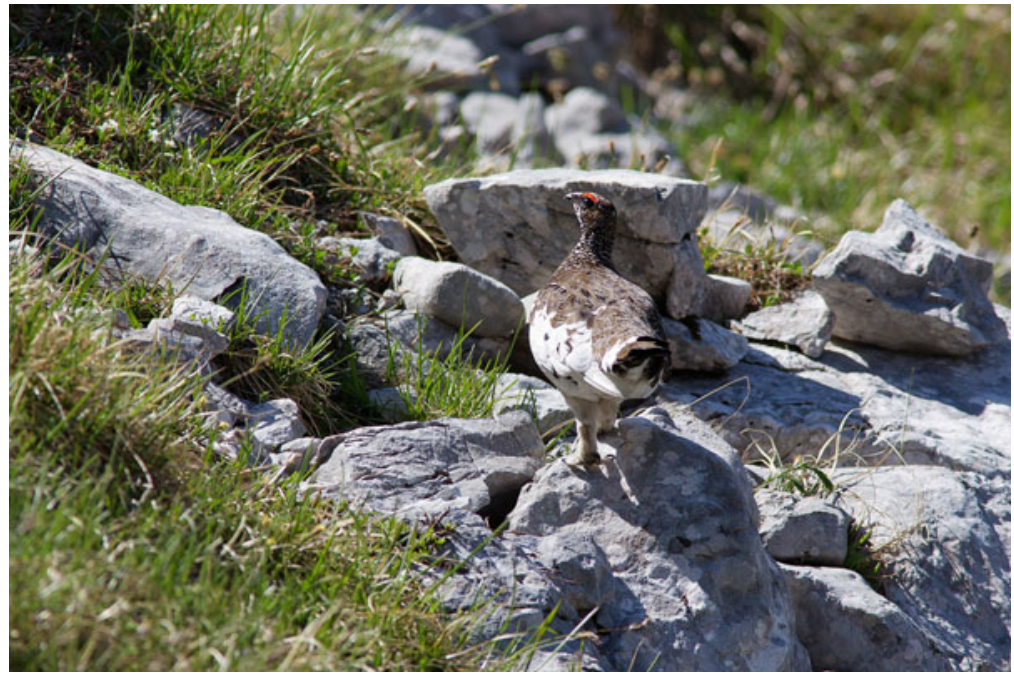

Fig. 12.1 Male of rock ptarmigan (Lagopus muta) in summer plumage (Photo: Luka Markež)

(Cramp and Simmons 1980). It occurs in flocks during autumn and winter, and is monogamous in breeding period. The rock ptarmigan is a species with short-distance movements during the year, in late summer it often moves only to higher altitudes (nival belt) (Cramp and Simmons 1980). In TNP, the species was observed within an elevation of 1,600-2,600 m a.s.l. during the summer period (Jančar 1997) and between 1,350 and 2,350 $\mathrm{m}$ a.s.l. during the winter period (Kmecl 1997). Optimal habitats for the species are grasslands, interspersed with smaller shrubs, high and small-scale variation of inclination and exposition. In winter both factors provide mosaics of variable snow cover and different snow heights, while during summer a variety of microclimates favour high plant and food diversity (Bossert 1980; Nopp-Mayr and Zohmann 2008). Size of territories in Alps varies between 10 and 35 ha, while the distribution, extent and numbers of territories appear to be rather stable for decades (Bossert 1980, 1995; Favaron et al. 2006). Breeding density varies among years and areas, and it is mostly estimated from 2 to 7 breeding pair per $\mathrm{km}^{2}$ (Bossert 1995; Peer 2005; Nopp-Mayr and Zohmann 2008).

Rock ptarmigan is evaluated as least concern species in IUCN Red List due to extremely large range and population size (BirdLife International 2012) and it is listed in Annex I of the EU Birds Directive (Direktiva 2009). In the Red Data book of Slovenia it has a status of vulnerable species (Ur. 1. RS 2002).

In contrast to the central distributional area of rock ptarmigan where the species still occupies most of the original range, some local declines in relatively small populations in Alps and Pyrenees, on the southern border of its distribution area, have been noted (Novoa et al. 2008; Revermann et al. 2012; Storch 2007). In some studies, based on the effect of climate on the rock ptarmigan and its related whitetailed ptarmigan (Lagopus leucurus), climate change has been recognised as one of the major factors influencing the population dynamics of these species (e.g. Revermann et al. 2012; Wang et al. 2002). 


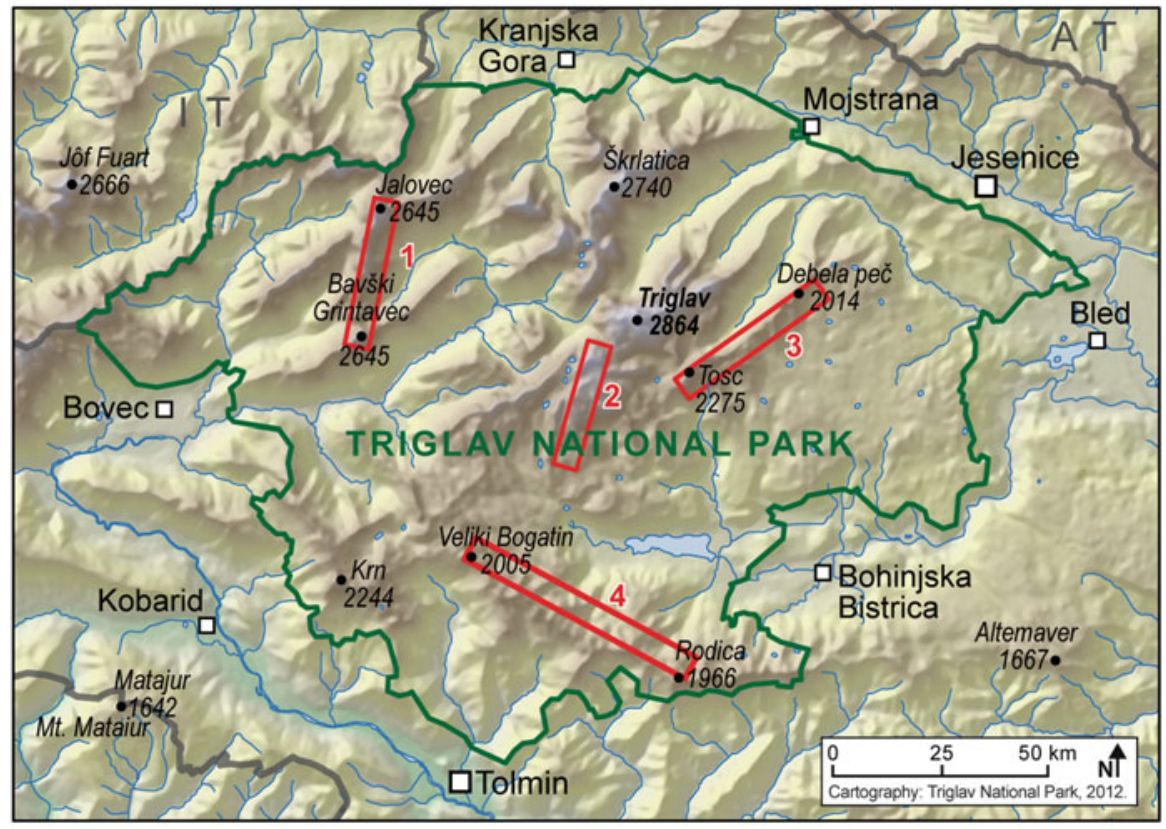

Fig. 12.2 Survey area of the mountain ranges: (1) Jalovec - Bavški Grintavec, (2) Kanjavec Mala Tičarica, (3) Debela peč - Tošc, (4) Veliki Bogatin - Črna prst (Cartography: Miha Marolt) (Public Information of Slovenia 2008)

Nevertheless, human influences, specially uncontrolled tourism (ski-resorts, recreation activities) still remains the most important impacts on the rock ptarmigan population in the Alps and Pyrenees (Storch 2007). As a consequence of mass tourism the population of Corvus species, which attack chicks and reduce breeding success, increase (Storch and Leidenberger 2003; Watson and Moss 2004). Although responses of the species to human disturbances differ between areas, mitigating human disturbances in core breeding areas is essential (Ellmauer et al. 2005).

The species distribution area in Slovenian Alps encompasses the Julian Alps, the Karavanke and the Kamniško-Savinjske Alps (Geister 1995). Its population in Triglav National Park is estimated at 100-300 breeding pairs (Jančar 1997). Due to the lack of surveys on rock ptarmigan in Slovenian Alps, no adequate published data on species population dynamics and distribution is available. Hence, there is a need for knowledge on its distribution, population density and trends, as well as a need to understand the disturbances that are influencing the species' population dynamics. The first samplings of rock ptarmigan in the TNP are restricted to the pilot areas of the mountain ranges: (1) Jalovec $(2,645 \mathrm{~m})-$ Bavški Grintavec (2,347 m); (2) Kanjavec (2,568 m) - Mala Tičarica (2,071 m); (3) Debela peč $(2,014 \mathrm{~m})$ - Tošc $(2,275 \mathrm{~m})$; (4) Veliki Bogatin $(2,005 \mathrm{~m})$ - Rodica $(1,966)$ (Fig. 12.2). Selected areas are under different level of human impacts, especially mountaineering, skiing and paragliding. Eventually, the pilot areas will also be implemented in other parts of TNP. Anyway, for better understanding the status of 
the alpine population of rock ptarmigan and its sufficient protection, the analysis of the monitoring results from the whole Alps would be necessary.

\subsection{Climate-Change Related Problems}

In order to predict the effects of climate change on the species population, knowledge of the effect of climate on its life history is essential (Novoa et al. 2008). Climate and weather characteristics are considered to be one of the most important factors influencing the population dynamics of rock ptarmigan. Breeding success, juvenile and adult survival heavily depends on weather conditions. Nesting success is negatively correlated with the amount of rainfall in particular during the hatching period (Novoa et al. 2008). The proportion of chicks in August depends on the onset of snow melt, mean minimal and maximal air temperatures during spring and early summer (Novoa et al. 2008). In all the species distribution models, the mean July temperature, annual precipitation, July water budget and July cloud cover were found to be the most powerful bioclimate variables for determining the distribution patterns of rock ptarmigan (Revermann et al. 2012). Furthermore, the powerful influence of the mean July temperature on rock ptarmigan distribution was stressed by Revermann et al. (2012) in connection with the heat dissipation limit theory (Speakman and Król 2010). Following this theory, we can explain the appearance of endothermic animals, including rock ptarmigan, in areas with lower temperatures in an attempt to avoid hyperthermia.

The increasing temperatures and smaller amounts of precipitation in winter months will result in a thinner snow layer. This means a lack of snow for deep burrows for roosting and sheltering in harsh winter conditions (Bossert 1980; Cramp and Simmons 1980; Hoffman and Braun 1977). Additionally, a decreased snow layer results in a deficiency of certain available food (Bossert 1980).

Events related to global warming, such as a higher frequency of extreme weather conditions, may affect hatching success, chick survival (Webb 1987 cited in Wilson and Martin 2008) and energy expenditure for food provisioning and thermoregulation of nesting females (Wiebe and Martin 1997 cited in Wilson and Martin 2008).

\subsection{Monitoring Objectives and Methods for Rock Ptarmigan Population}

Counting of calling males is based on the fact, that displaying proceeds inside territories or on borders and that territory borders may remain unchanged for decades. Territorial males can be heard for distances $\geq 1 \mathrm{~km}$ (Bossert 1977). The most important monitoring goals in TNP are:

1. To determine the distribution and dynamics of rock ptarmigan populations by direct observations, callings, and tracks, like feathers, droppings, footprints etc. (monitoring and dispersed observations): all year. 
Table 12.1 Sampling form for rock ptarmigan (Lagopus muta)

\begin{tabular}{|c|c|c|c|}
\hline $\begin{array}{l}\text { Sampling form for } \\
\text { rock ptarmigan }\end{array}$ & Name of observer & Datum of observation & Sampling unit \\
\hline $\begin{array}{l}\text { Time of sampling } \\
\text { (from-to) }\end{array}$ & Cloudiness & Wind & Precipitation \\
\hline $\begin{array}{l}\text { Patchiness of snow } \\
\text { cover }\end{array}$ & Habitat description & $\begin{array}{l}\text { Corvid-species and } \\
\text { their number }\end{array}$ & $\begin{array}{l}\text { Presence of Aquila } \\
\text { chrysaetos, Accipiter } \\
\text { gentilis and Falco } \\
\text { peregrinus, and the } \\
\text { number of individuals }\end{array}$ \\
\hline $\begin{array}{l}\text { Mammal species and } \\
\text { their number }\end{array}$ & Human impacts & - & - \\
\hline $\begin{array}{l}\text { ID of individual + } \\
\quad(\hat{\jmath}, q)\end{array}$ & $\begin{array}{l}\text { Behaviour (calling, } \\
\text { displaying, flying, } \\
\text { feeding. . .) }\end{array}$ & $\begin{array}{l}\text { Time of observation } \\
\text { of each individual }\end{array}$ & $\begin{array}{l}\text { Time of successive calls } \\
\text { of each male }\end{array}$ \\
\hline
\end{tabular}

2. To investigate the population densities in TNP with standardised counting of displaying and calling: May-June.

3. To estimate breeding success by field observations of females with chicks and nest records and with help of radio-transmitters (Wilson and Martin 2008): July.

4. To describe habitat requirements of the species by vegetation sampling, remote sensing techniques and environmental parameters: June-August.

5. To identify the link between climatic factors, influencing on species population dynamics (Meteorological station).

6. To determine major impacts on the species population with help of monitoring human impacts and environmental conditions: all year.

7. To identify ecological relationships between rock ptarmigan and other species: all year.

8. To develop a model of potential species distribution with considering changing in climate: combining results from long-term surveys and mathematical modelling. With population viability analysis (PVA) the different management scenarios and assessment of the potential impacts of habitat loss will be evaluated. In the models and analysis the whole alpine rock ptarmigan population will be included.

The method is recapped from Bossert $(1977,1995)$. The study area is divided into sections that are separated by topographic structures (ridges, mountain passes). In study plots numbers of simultaneously calling males are determined by a team of stationary observers that will cover the whole sampling area. Observation points within potential ptarmigan habitats were selected in the field according to good visibility and audibility. Sampling proceeds between the end of May and the beginning of July during early morning hours from 3:00 to 7:00 (8:00) CTE. Individual observations of the species seeing or callings, together with observation sites (points), are recorded on map 1:3,500 and documented in the sampling form (Table 12.1). Monitoring surveys will be performed in 5 year intervals.

The topographic parameters (elevation, exposition and slope aspect) (Wilson and Martin 2008) and habitat types will be sampled in order to described 
environmental characteristics of rock ptarmigan's territory. Additionally, more detailed vegetation sampling will be done in feeding and nesting habitats. With the use of aerial photography, the vegetation changes - succession in the rock ptarmigan's habitat will be detected.

The human impacts will be evaluated indirectly, due to the presence of Corvidspecies, the number of accommodations in mountain huts, and by direct observations of human disturbances in the field.

\subsection{Expected Results of Climate Change Impacts on Rock Ptarmigan Population}

Like in other Alpine countries (e.g. Beniston 1997; Keiler et al. 2010), changes of some climate factors were already observed in Slovenian Alps. The increase of mean annual, minimal and maximal temperatures in the period from 1961 to 2011 is statistically significant in all analysed meteorological stations in TNP (547-2,514 $\mathrm{m}$ a.s.1.). Furthermore, the negative trends in the number of days with snow cover during snow season were also noted (Črepinšek et al. 2012). Considering those environmental changes, we expect alterations in population and distribution of rock ptarmigan, as well as changes of its habitat. In particular, due to its strong dependence on weather conditions during the breeding season, the breeding phenology and breeding success are expected to be largely effected.

Following the effects of climate changes which have already been detected in some alpine grassland vegetation (Cannone et al. 2007; Körner 1999; Keller et al. 2000), we predict accelerating plant succession by which the proportion of woody species will increase. Additionally, the tree-line will shift upwards to higher altitudes. This process is expected to proceed faster in dry habitats on carbonate ground, which is widespread in the Slovenian Alps. Similar results are presumed in species distribution modelling where due to increasing temperatures during the breeding season, potential habitats are expected to decrease by up to two-thirds of area by the year 2070 (Revermann et al. 2012). Such vegetation changes could reduce suitable habitats for rock ptarmigan resulting in the greater isolation of already fragmented populations (Storch 2007) and consequently lower gene flow exchange between them.

Additionally, the increase overlap between rock ptarmigan and other grassland bird and/or small mammal species, causing greater competition between them, is expected. So far, only few published data on interactions between rock ptarmigan and other grassland species exist. The evidence about alpine marmot predation on rock ptarmigan nests were reported from the Alps (Jordana et al. 2006 cited in Figueroa et al. 2009), whereas the results from Pyrenees suggest that such interaction is only a sporadic event (Figueroa et al. 2009).

Finally, the loss of appropriate habitats with increasing human disturbances, lower breeding success, as well as greater interspecific competition could affect the viability of rock ptarmigan population in a level that cause the decline or extinction of local populations. 


\subsection{Conclusions for Nature Conservation and Management of Rock Ptarmigan Population in Triglav National Park}

Due to the lack of basic data on the species' distribution and influences of environmental and human impacts on population numbers, active conservation management of rock ptarmigan in TNP does not exist, yet. With the help of long-term surveys and related research the park should be able to implement appropriate management measures for conserving viable populations of this species. Anyway, with the monitoring results the management authority of TNP will be able (1) to determine what environmental factors and human activities influencing rock ptarmigan population distribution and dynamics, (2) to determine the areas with specific restrictions and areas with strict protection, and (3) to define the areas where the corridors should be implemented.

For conservation purposes the monitoring programme should answer the following questions:

1. How will climate change effect the species' distribution and population numbers in TNP?

2. How will human impacts effect the species' distribution and population numbers in TNP?

3. How will vegetation changes effect seasonal movements, distribution, reproduction, and diet for the species?

4. Which species will compete for habitat, food and other resources in a changing environment with ptarmigans?

5. Where are potential future nesting and wintering habitats for ptarmigan population in TNP?

The present research will provide the introduction to gathering answers to the above questions.

The conservation of appropriate habitats (Fig. 12.3) is probably the most important management strategy for maintaining a viable population of rock ptarmigan when declines in local populations of this species will be observed due to climate change. Especially the areas with large variation in topographic and geomorphologic structures (Fig. 12.4) are particularly important, because they provide better potential for the birds to adapt to weather fluctuations by taking advantage of differences in microsite-specific climates (Favaron et al. 2006; Revermann et al. 2012). Therefore, the strict protection - the closure of some of such areas together with the highest peaks of the mountains within TNP should be provided. Those areas should serve as the last breeding refugia as the breeding place is expected to shift to the higher elevations. Additionally, the establishment and maintenance of the corridors connections will contribute to gene exchange with other local populations.

The anthropogenic pressures, like: (1) ski touring, (2) paragliding, (3) mountaineering, (4) intensive pasture, should be limited or prohibited where they are recognised as a treat to the species. In such habitats with reduced additional stresses, the species is 


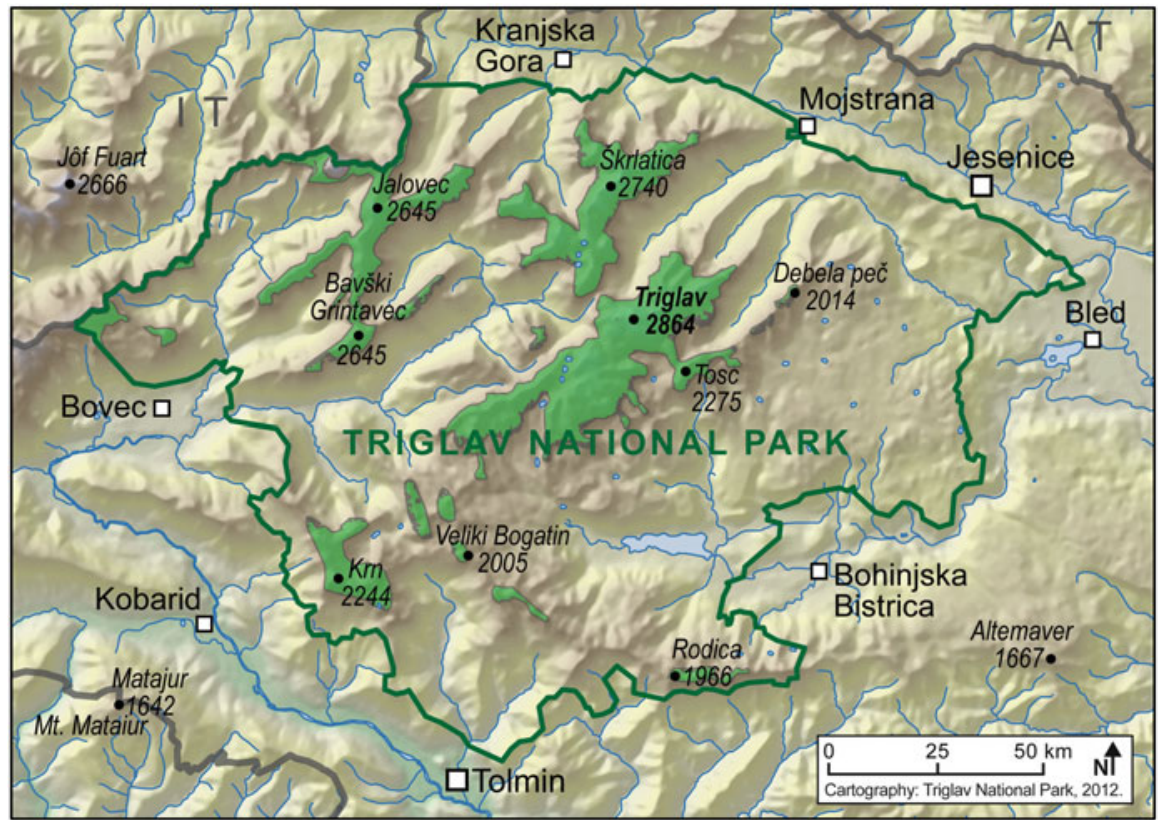

Fig. 12.3 Potential future nesting and wintering habitats in terms of habitat and altitudinal aspect for the rock ptarmigan (Lagopus muta) population in TNP (Cartography: Miha Marolt) (Jarvis et al. 2008)

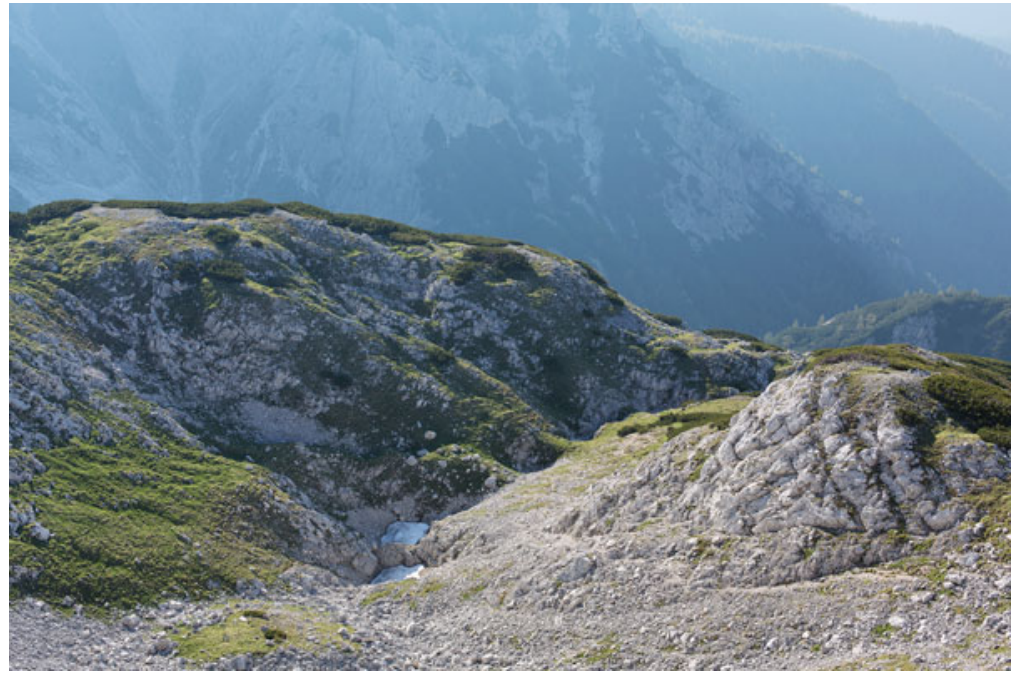

Fig. 12.4 Typical habitat for rock ptarmigan with diverse relief structures (Photo: Luka Markež) 
more likely to adapt to environmental changes. According to human pressures on rock ptarmigan population, the closed areas should be defined, or time and space limitations in areas with rock ptarmigan presence should be ensured.

The use of population viability analysis and applying species distribution models to identify the treats and suitable habitats for rock ptarmigan are, in addition to monitoring and scientific research, the most important task in adaptive conservation strategies. Species-habitat relationship modelling helps to organise and document factors associated with habitat evaluation and planning as well as provide help to monitor species and environments (Guisan and Thuiller 2005; Morrison et al. 1978).

Considering the small population size and naturally fragmented populations of rock ptarmigan in the Alps (Favaron et al. 2006; Storch 2007) genetic approaches in species conservation are particularly important. Furthermore, the knowledge on genetic basis of selectively favoured phenotypes allows the prediction and mitigation of the effects of climate change on population viability (Reusch and Wood 2007 cited in Oyler-McCance et al. 2011).

Finally, the understanding of species ecology, interactions with other species and potential overlapping ecological niches will be possible with long-term monitoring and scientific research. So far, the interactions of rock ptarmigan, corvids (Corvus sp.), alpine marmots (Marmota marmota) and golden eagle (Aquila chrysaetos) were observed and analysed under different conditions or situations (Figueroa et al. 2009; Storch and Leidenberger 2003; Watson and Moss 2004). In order to include predictions of such complex species interactions in changing environmental conditions or under human impact in our park's management issues will require more specific studies.

Acknowledgements The present study was carried out under the "Adaptive Management of Climate-induced changes of Habitat Diversity in Protected Areas" ("HABIT-CHANGE") project, supported by Central Europe. First and foremost, I would like to thank to our project coordinator Sven Rannow and project manager Marco Neubert for the valuable guidance and advice during writing a paper. Special thanks go to both referees, Andrej Sovinc, Peter Sackl and one anonymous author who improved the manuscript with their constructive reviews and helpful comments. I would also like to thank Miha Marolt for providing the maps and Luka Markež for providing photos. Finally, I am very grateful to Tanja Menegalija, the project coordinator in Triglav National Park, who gave me the opportunity to work on that project.

Open Access This chapter is distributed under the terms of the Creative Commons Attribution Noncommercial License, which permits any noncommercial use, distribution, and reproduction in any medium, provided the original author(s) and source are credited.

\section{References}

Alexander, M. (2008). Management planning for nature conservation. A theoretical basis \& practical guide. Barmouth: Springer.

Beniston, M. (1997).Variations of snow depth and duration in the Swiss Alps over the last 50 years: Links to changes in large-scale climatic forcings. Climatic Change, 36, 281-300. Retrieved June 28, 2012, from http://www.unige.ch/climate/Publications/Beniston/CC97B.pdf 
BirdLife International. (2012). Lagopus muta. In IUCN red list of threatened species. Retrieved June 12, 2012, from http://www.birdlife.org/datazone/speciesfactsheet.php?id=291

Bossert, A. (1977). Bestandesaufnahmen am Alpenschneehuhn (Lagopus mutus) im Aletschgebiet. Ornithol Beob, 74, 95-98.

Bossert, A. (1980). Winterökologie des Alpenschneehuhns (Lagopus mutus Montin) im Aletschgebiet. Schweizer Alpen Ornithol Beob, 77(3), 121-166.

Bossert, A. (1995). Bestandsentwicklung und Habitatnutzung des Alpenschneehuhns Lagopus mutus im Aletschgebiet (Schweizer Alpen). Ornithol Beob, 92, 307-314.

Cannone, N., Sgorbati, S., \& Guglielmin, M. (2007). Unexpected impacts of climate change on alpine vegetation. Frontiers in Ecology and the Environment, 5(7), 360-364. Retrieved June 28, 2012, from http://www.mendeley.com/research/unexpected-impacts-of-climate-changeon-alpine-vegetation/

Cramp, S., \& Simmons, K. E. L. (Eds.). (1980). The birds of Western Palearctic (Vol. 2). Oxford: Oxford University Press.

Črepinšek, Z., Kralj, T., Kunšič, A., \& Kajfež-Bogataj, L. (2012). Nekatere podnebne značilnosti Triglavskega narodnega parka z okolico za obdobje 1961-2011. Acta Triglavensia, 1, 23-41.

Direktiva 2009/147/ES Evropskega parlamenta in sveta z dne 30. novembra 2009 o ohranjanju prosto živečih ptic. Retrieved February 22, 2011, from http://eur-lex.europa.eu/LexUriServ/ LexUriServ.do?uri=OJ:L:2010:020:0007:0025:SL:PDF

Ellmauer, T., Dvorak, M., \& Wichmann, G. (2005). Entwicklung von Kriterien, Indikatoren und Schwellenwerten zur Beurteilung des Erhaltungszustandes der Natura 2000-Schutzgueter. Retrieved April 17, 2011, from http://www.umweltbundesamt.at/fileadmin/site/umweltthe men/naturschutz/Berichte_GEZ/Band_1_Vogelarten.pdf

Favaron, M., Scherini, G. C., Preatoni, D., Tosi, G., \& Wauters, L. A. (2006). Spacing behaviour and habitat use of the rock ptarmigan (Lagopus mutus) at low density in the Italian Alps. Journal of Ornithologie, 147, 618-628. Retrieved June 5, 2012, from http://www.springerlink. com/content/t0m474259p588544/fulltext.pdf

Figueroa, I., López, B. C., López, A., \& Potrony, D. (2009). What happens to ptarmigan when marmots arrive? Ethology Ecology \& Evolution, 21, 251-260. Retrieved June 11, 2012, from ftp://gis.dipbsf.uninsubria.it/nuova\%20cartella/Figueroa_et_al_2009.pdf

Geister, I. (1995). Ornitološki atlas Slovenije. Ljubljana: Državna založba Slovenije.

Guisan, A., \& Thuiller, W. (2005). Predicting species distribution: Offering more than simple habitat models. Ecology Letters, 8, 993-1009. Retrieved June 27, 2012, from http:// onlinelibrary.wiley.com/doi/10.1111/j.1461-0248.2005.00792.x/pdf

Hoffman, R., \& Braun, C. E. (1977). Characteristics of a winter population of white-tailed ptarmigan in Colorado. The Wilson Bulletin, 89(1), 107-115. Retrieved June 27, 2012, from http://library.unm.edu/sora/Wilson/v089n01/p0107-p0115.pdf

Jančar, T. (1997). Ornitološki atlas gnezdilk Triglavskega narodnega parka. Ljubljana: DOPPS.

Jarvis, A., Reuter, H. I., Nelson, A., \& Guevara, E. (2008). Hole-filled seamless SRTM data V4, International Centre for Tropical Agriculture (CIAT). Retrieved June 27, 2012, from http:// srtm.csi.cgiar.org

Keiler, M., Knight, J., \& Harrison, S. (2010). Climate change and geomorphological hazards in the eastern European Alps. Philosophical Transactions of the Royal Society A, 368, 2461-2479. Retrieved June 28, 2012, from http://rsta.royalsocietypublishing.org/content/368/1919/2461. full.pdf + html

Keller, F., Kienast, F., \& Beniston, M. (2000). Evidence of response of vegetation to environmental change on high-elevation sites in the Swiss Alps. Regional Environmental Change, 1 (2), 7-77. Retrieved December 14, 2010, from http://www.springerlink.com/content/ jq74cb9xwalcv9ep/fulltext.pdf

Kmecl, P. (1997). Zimski ornitološki atlas Triglavskega narodnega parka. Projektno poročilo. Ljubljana: DOPPS.

Körner, C. (1999). Alpine plant life: Functional plant ecology of high mountain ecosystems. Berlin: Springer. 
Morrison, M. L., Marcot, B. G., \& Mannan, R. W. (1978). Wildlife-habitat relationships. Concepts \& applications. Madison: The University of Wisconsin Press.

Nopp-Mayr, U., \& Zohmann, M. (2008). Spring densities and calling activities of Rock Ptarmigan (Lagopus muta helvetica) in the Austrian Alps. Journal of Ornithologie, 149, 135-139. Retrieved April 17, 2011, from http://www.springerlink.com/content/6538qk4878374417/ fulltext.pdf

Novoa, C., Besnard, A., Brenot, J. F., \& Ellison, L. N. (2008). Effect of weather on the reproductive rate on Rock Ptarmigan Lagopus muta in the eastern Pyrenees. Ibis, 150(2), 270-278. Retrieved June 19, 2012, from http://onlinelibrary.wiley.com/doi/10.1111/j.1474919X.2007.00771.x/pdf

Oyler-McCance, S. J., Stricker, C. A., John, J. St., Braun, C. E., Wann, G. T., O’Donnell, M. S., \& Aldridge, C. L. (2011). Effects of climate change on nutrition and genetics of white-tailed Ptarmigan. In B. Sandercock, K. Martin, \& G. Segelbacher (Eds.), Ecology, conservation, and management of grouse (Studies in avian biology, Vol. 39, pp. 283-294). Berkeley: University of California Press. Retrieved June 28, 2012, from http://www.fort.usgs.gov/Products/Publica tions/23450/23450.pdf

Peer, K. (2005). Habitat merkmale von Brutrevieren des Alpenschneehuhns (Lagopus mutus) im Kühtai, Tirol. Egretta, 48(1-2), 35-44. Retrieved June 12, 2011, from http://www. landesmuseum.at/pdf_frei_remote/EGRETTA_48_1_2_0035-0044.pdf

Primack, R. B. (2006). Essentials of conservation biology. Sunderland: Sinauer Associates.

Revermann, R., Schmid, H., Zbinden, N., Spaar, R., \& Schroder, B. (2012). Habitat at the mountain tops: How long can Rock Ptarmigan (Lagopus muta helvetica) survive rapid climate change in the Swiss Alps? A multi-scale approach. Journal of Ornithology. Retrieved June 5, 2012, from http://www.springerlink.com/content/p70572531tk74j80/fulltext.pdf

Speakman, J. R., \& Król, E. (2010). Maximal heat dissipation capacity and hyperthermia risk: Neglected key factors in the ecology of endotherms. Journal of Animal Ecology, 79, 726-746. Retrieved June 6, 2012, from http://onlinelibrary.wiley.com/doi/10.1111/j.1365-2656.2010. 01689.x/pdf

Storch, I. (Eds.). (2007). Grouse: Status Survey and Conservation Action Plan 2006-2010. Gland/ Fordingbridge: IUCN/World Pheasant Association. Retrieved June 11, 2012, from http://data. iucn.org/dbtw-wpd/edocs/2007-034.pdf

Storch, I., \& Leidenberger, C. (2003). Tourism, mountain huts and distribution of corvids in the Bavarian Alps, Germany. Wildlife Biology, 9(4), 301-308. Retrieved April 17, 2011, from http://www.wildlife.uni-freiburg.de/dateien/paper/storchleidenberger2003

Ur. 1. RS, št. 82. (2002). Rdeči seznam ptičev gnezdilcev (Aves). Retrieved February 22, 2011, from http://www.uradni-list.si/_pdf/2002/Ur/u2002082.pdf

Wang, G., Hobbs, N. T., Giesen, K. M., Galbraith, H., Ojima, D. S., \& Braun, C. E. (2002). Relationships between climate and population dynamics of white-tailed ptarmigan Lagopus leucurus in Rocky Mountain National Park, Colorado, USA. Climate Research, 23, 81-87. Retrieved June 13, 2012, from http://www.int-res.com/articles/cr2003/23/c023p081.pdf

Watson, A., \& Moss, R. (2004). Impacts of ski-development on ptarmigan (Lagopus mutus) at Cairn Gorm, Scotland. Biological Conservation, 116, 267-275. Retrieved April 17, 2012, from http://www.wwf.it/UserFiles/File/AltriSitiWWF/Piemonte/documenti/ecosistemi/Impatti\%20 turismo\%20invernale_approfondimenti/2004_Impact\%20ski-development\%20on\%20Lagopus $\% 20$ mutus.pdf

Wilson, S., \& Martin, K. (2008). Breeding habitat selection of sympatric White-tailed, Rock and Willow Ptarmigan in the southern Yukon Territory, Canada. Journal of Ornithology, 149, 629-637. Retrieved April 17, 2012, from http://www.calgarybirdbandingsociety.org/docu ments/Ptarmigan\%20habitat\%20selection.pdf 